\title{
SYSTEM REQUIREMENT ANALYSIS OF A CONSTRUCTION DELAY ANALYSIS SYSTEM
}

\author{
Jyh-Bin Yang*, Chih-Kuei Kao and Yi-Yao Lee \\ Institute of Construction Management \\ Chung Hua University \\ No. 707, Sec. 2, Wu-Fu Rd., Hsinchu 300, Taiwan \\ *jyhbin@chu.edu.tw
}

\begin{abstract}
When the completion of a project is delayed, how to accurately analyze the impact of a delayed activity on the project is a main problem for construction project managers. Available professional scheduling tools have been widely employed to plan and control construction schedules. They are not designated for delay analysis that requires numerous computation scenarios by different views. Therefore, a comprehensive management information system (MIS) for schedule delay analysis is needed for schedule delay management. The first step of developing an MIS is to carry out the task of system requirement analysis. This study used the method of IDEFØ, a structured analysis and design technique, to portray the contents of an MIS for schedule delay analysis. Based on the results of this study, further system implementation will be easy to do. Furthermore, the research results can also be used to necessary examination for delay claim preparations.
\end{abstract}

Keywords: Schedule Delay Analysis, System Analysis, MIS, IDEFØ

\section{INTRODUCTION}

When the completion of a project is delayed, how to accurately analyze the impact of a delayed activity on the project is a main problem for construction project managers. Available professional scheduling tools have been widely employed to plan and control construction schedules, but not designated for delay analysis that requires numerous computation scenarios by different views. There are several delay analysis methodologies developed in the past few years. Nearly all methodologies require the as-planned and as-built schedules for delay analysis. The as-planned schedule represents the contractor's original plan for completing the work required by the contract documents and approved by the owner; the as-built schedule depicts the actual start and finish dates and sequence of activities as they occurred during the project. The as-planned and as-built schedules were usually represented by different formats, i.e. bar chart or precedence diagram or arrow diagram, and prepared by different software. Although few commercial delay analysis software systems are available now, they can not fit the requirements of different users, different platforms, and different professional scheduling tools employed by users. The analysis process of existed systems seems to be a black box for the users if they try to do further analysis by themselves [1]. There is a need to analyze the system requirement of a construction delay analysis system that is beneficial to develop a transparent system.

IDEFØ is a structured analysis and design technique for reflecting how system functions interrelate and operate. For a new system, IDEFØ may be used first to define the requirements and specify the functions, and then to design an implementation that meets the requirements and performs the functions. IDEFØ model provides a blueprint of functions and their interfaces that must be captured and understood in order to make systems engineering decisions that are logical, affordable, and achievable [2]. Therefore, this study employed IDEFØ as a tool to represent the system requirement of a construction delay analysis system.

\section{LETERATURE REVIEW}

\subsection{Delay Analysis Prototypes}

Yates (1993) [3] developed a construction decision support system for delay analysis with the capability of determining possible causes for project delays. The system used some information technology (IT) to deal with data processing for delay analysis. Riad et al. (1995) [4] developed a LISP program to help users to identify the schedule impact under project acceleration. The program generated the as-planned, as-built, projected, adjusted, owner-accountable and contractor-accountable schedules based on general project appraisal information. Alkass et al. (1995) [5] used one delay analysis methodology, the isolated delay type technique, and integrated some commercial software packages of project management system, database, spreadsheets, word processors, and expert system to develop a well functioning system for delay claim analysis. Based on the knowledge-based techniques, Aoude (1996) [6] developed a computer program to assist in identifying and quantifying delays encountered in construction projects. The system used general project appraisal information to analyze project and activity level delays. A multimedia system for construction delay management was discussed by Abudayyeh (1997) [7]. The purpose of the system was to demonstrate how pictorial and audio data and information play key roles in the management of delays and potential claims. Table 1 summarizes the used tools or techniques as well as their purposes of above prototypes. 
Table 1 Review on computerized delay analysis

\begin{tabular}{|l|l|l|}
\hline Author(s), Year & \multicolumn{1}{|c|}{$\begin{array}{c}\text { Used } \\
\text { tools/techniques }\end{array}$} & \multicolumn{1}{c|}{ Purpose } \\
\hline $\begin{array}{l}\text { Yates, J.K., } \\
\text { Decision support } \\
\text { system }\end{array}$ & $\begin{array}{l}\text { determining } \\
\text { possible causes }\end{array}$ \\
\hline $\begin{array}{l}\text { Arditi, D. \& } \\
\text { Mohammadi, J., } \\
1995\end{array}$ & LISP program & $\begin{array}{l}\text { identify } \\
\text { schedule impact } \\
\text { for project } \\
\text { acceleration }\end{array}$ \\
\hline $\begin{array}{l}\text { Alkass, S., } \\
\text { Mazerolle, M., } \\
\text { Tribaldos, E., \& } \\
\text { Harris, F., 1995 }\end{array}$ & $\begin{array}{l}\text { General computer } \\
\text { program }\end{array}$ & $\begin{array}{l}\text { quantifying } \\
\text { delays }\end{array}$ \\
\hline $\begin{array}{l}\text { Aoude, H.M. } \\
\text { 1996 }\end{array}$ & $\begin{array}{l}\text { Knowledge-based } \\
\text { techniques }\end{array}$ & $\begin{array}{l}\text { identifying and } \\
\text { quantifying } \\
\text { delays }\end{array}$ \\
\hline $\begin{array}{l}\text { Abudayyeh, } \\
\text { O.Y., 1997 }\end{array}$ & Multimedia & $\begin{array}{l}\text { delay data } \\
\text { management }\end{array}$ \\
\hline
\end{tabular}

\subsection{Commercial Systems}

There are few commercial software systems for delay analysis designated for construction projects. The software systems include: Schedule Analyzer ProfessionalTM [8], Primavera $^{\circledR}$ Claim Digger ${ }^{\mathrm{TM}}$ [9], Tipper ${ }^{\mathrm{TM}}$ [10] and Sure Change $^{\mathrm{TM}}$ [11]. Yang (2005) ever compared the available systems and concluded that above systems can provide users batch programs to run various comparisons between the as-planned and the as-built schedules, but these systems are not the panacea to resolve delay claims [1]. Completely recording and keeping all schedule information about delays is the basic requirement for delay analysis. Furthermore, the analysis process of above systems seems to be a black box for the users if they try to do further analysis by themselves. It is necessary to analyze the system requirement of a satisfying construction delay analysis system.

\section{IDEFØ}

\subsection{Basic Concepts}

IDEFØ (Integration DEFinition language 0) is based on SADT (Structured Analysis and Design Technique), developed by Douglas T. Ross and SofTech, Inc. [12]. IDEFØ consists of a definition of a graphical modeling language (syntax and semantics) and a description of a comprehensive methodology for developing models. It is used to a function model that is a structured representation of the functions, activities or processes within the modeled system or subject area. IDEFØ is an engineering technique for performing and managing needs analysis, benefits analysis, requirements definition, functional analysis, systems design, maintenance, and baselines for continuous improvement [12].

Figure 1 shows a typical IDEFØ graph that represents its syntax (graphical component) and semantics (meaning). In that, the activity box provides a description of what happens in a designated function; the arrow conveys data or objects related to functions to be performed. There are four types of arrows in an IDEFØ graph. The input arrow expresses the data or objects that are transformed by the function into output, and is associated with the left side of an IDEFØ box. The output arrow expresses the data or objects produced by a function (a box), and is associated with the right side of an IDEFØ box. The control arrow expresses the conditions required to produce correct output, and is associated with the top side of an IDEFØ box. The mechanism arrow expresses the means used to perform a function, and is associated with the bottom side of an IDEFØ box.

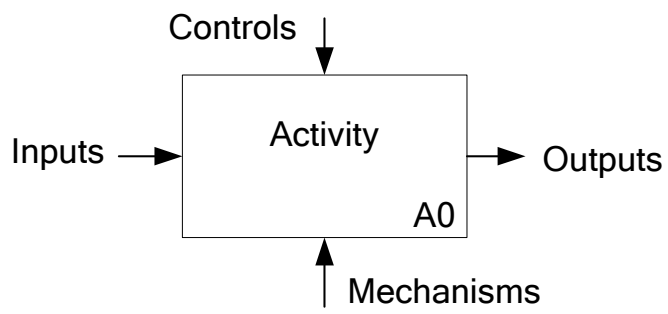

Figure 1 Typical IDEFØ graph

\subsection{Strengths and Weaknesses}

The primary strength of IDEFØ is that the method has proven effective in detailing the system activities for function modeling [13]. Activities depicted on IDEFØ can be described by their inputs, outputs, controls, and mechanisms. Therefore, IDEFØ provides a systematic view for readers.

One of the observed problems with IDEFØ models is that they often are so concise that they are understandable only if the reader is a domain expert or has participated in the model development [13]. Although IDEFØ has some limitations, it still has many real applications in various domains.

\subsection{Application in Construction}

Sarkis and Liles (1995) integrated Quality Function Deployment and IDEFØ functional modeling to determine the requirements and processes for the strategic justification of computer-integrated enterprise technologies for small and medium-sized manufacturing enterprises [14]. In order to improve the efficiency and effectiveness of model development, Chen et al. (2004) proposed an augmented IDEF1-based process-oriented information modeling methodology, which integrates the IDEF0 process model with the enhanced IDEF1 information model by which the information requirements can be easily identified and analyzed through the corresponding process models [15]. The proposed model is examined by a simple implementation of the integration of architectural design and structural design.

Tserng and Lin (2004) proposed the concept of integrating IDEF modeling methods with a novel 
Construction Activity-Based Knowledge Management (ConABKM) model for designing construction knowledge management systems [16]. IDEFØ was applied to understand the necessary function for consideration in the knowledge flow process model.

\section{DELAY ANALYSIS METHODOLOGY}

\subsection{Available Methods}

There are many delay analysis methods found in the literature [1, 17-20]. The famous methods include: Global Impact Technique, Net Impact Technique, Adjusted As-built CPM Technique, As-planned Expanded Technique (What-if Technique, As-planned Plus Delay Technique), But-for Technique (As-built Collapsing Technique, Collapsed As-built Technique, But-for Analysis Using As-planned CPM), Snapshot Technique, Time Impact Technique (Modified As-built Method), Windows Technique (Contemporaneous Period Analysis), Modified Windows Approach and Isolated Delay Type Technique. All these methods can be grouped into four categories: concept method, forward path method, backward path method and dynamic method. Table 2 shows the categories and their meanings.

\subsection{Simulated Delay Analysis Method}

The but-for technique (also termed as the collapsed as-built method) is used to present delays and time extension requests after a project is built [18]. This technique attempts to remove one party's delay from the as-built schedule (to collapse the schedule) and leaves those delays caused solely by the other party. Figure 2 displays the analysis process.
Table 2 Delay analysis methodologies and their meanings

\begin{tabular}{|c|c|c|}
\hline Category & Method & Descriptions \\
\hline $\begin{array}{l}\text { Concept } \\
\text { method }\end{array}$ & $\begin{array}{l}\text { Global Impact } \\
\text { Technique, } \\
\text { Net Impact } \\
\text { Technique } \\
\end{array}$ & $\begin{array}{l}\text { Simply calculating } \\
\text { delay value by } \\
\text { examining final } \\
\text { schedule evidences }\end{array}$ \\
\hline $\begin{array}{l}\text { Forward } \\
\text { path } \\
\text { method }\end{array}$ & $\begin{array}{l}\text { Adjusted As-built } \\
\text { CPM Technique, } \\
\text { As-planned } \\
\text { Expanded } \\
\text { Technique }\end{array}$ & $\begin{array}{l}\text { Systematically } \\
\text { calculating delay } \\
\text { value from } \\
\text { as-planned } \\
\text { schedule forward } \\
\text { to as-built schedule }\end{array}$ \\
\hline $\begin{array}{l}\text { Backward } \\
\text { path } \\
\text { method }\end{array}$ & $\begin{array}{l}\text { But-for Technique, } \\
\text { Time Impact } \\
\text { Technique }\end{array}$ & $\begin{array}{l}\text { Systematically } \\
\text { calculating delay } \\
\text { value from as-built } \\
\text { schedule backward } \\
\text { to as-planned } \\
\text { schedule }\end{array}$ \\
\hline $\begin{array}{r}\text { Dynamic } \\
\text { method }\end{array}$ & $\begin{array}{l}\text { Snapshot Technique, } \\
\text { Windows } \\
\text { Technique, } \\
\text { Modified Windows } \\
\text { Approach, } \\
\text { Isolated Delay Type } \\
\text { Technique }\end{array}$ & $\begin{array}{l}\text { Systematically } \\
\text { calculating delay } \\
\text { value in } \\
\text { determined time } \\
\text { frames forward or } \\
\text { backward }\end{array}$ \\
\hline
\end{tabular}

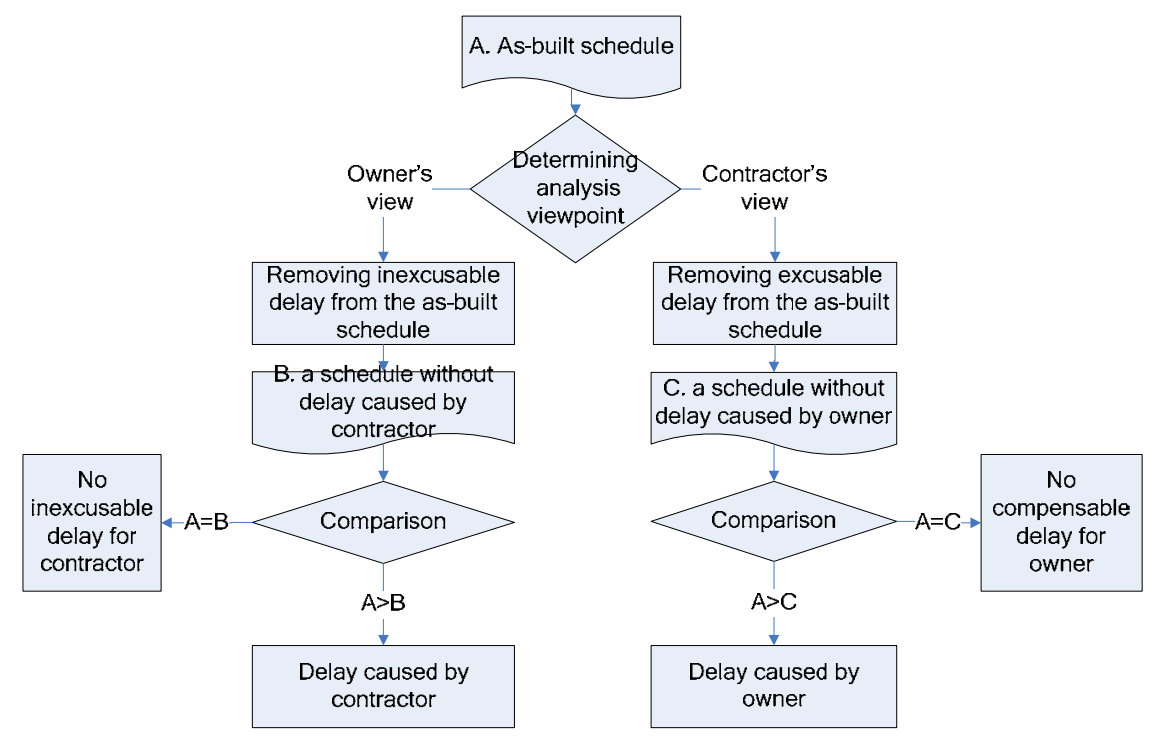

Figure 2 Analysis process for the but-for technique 


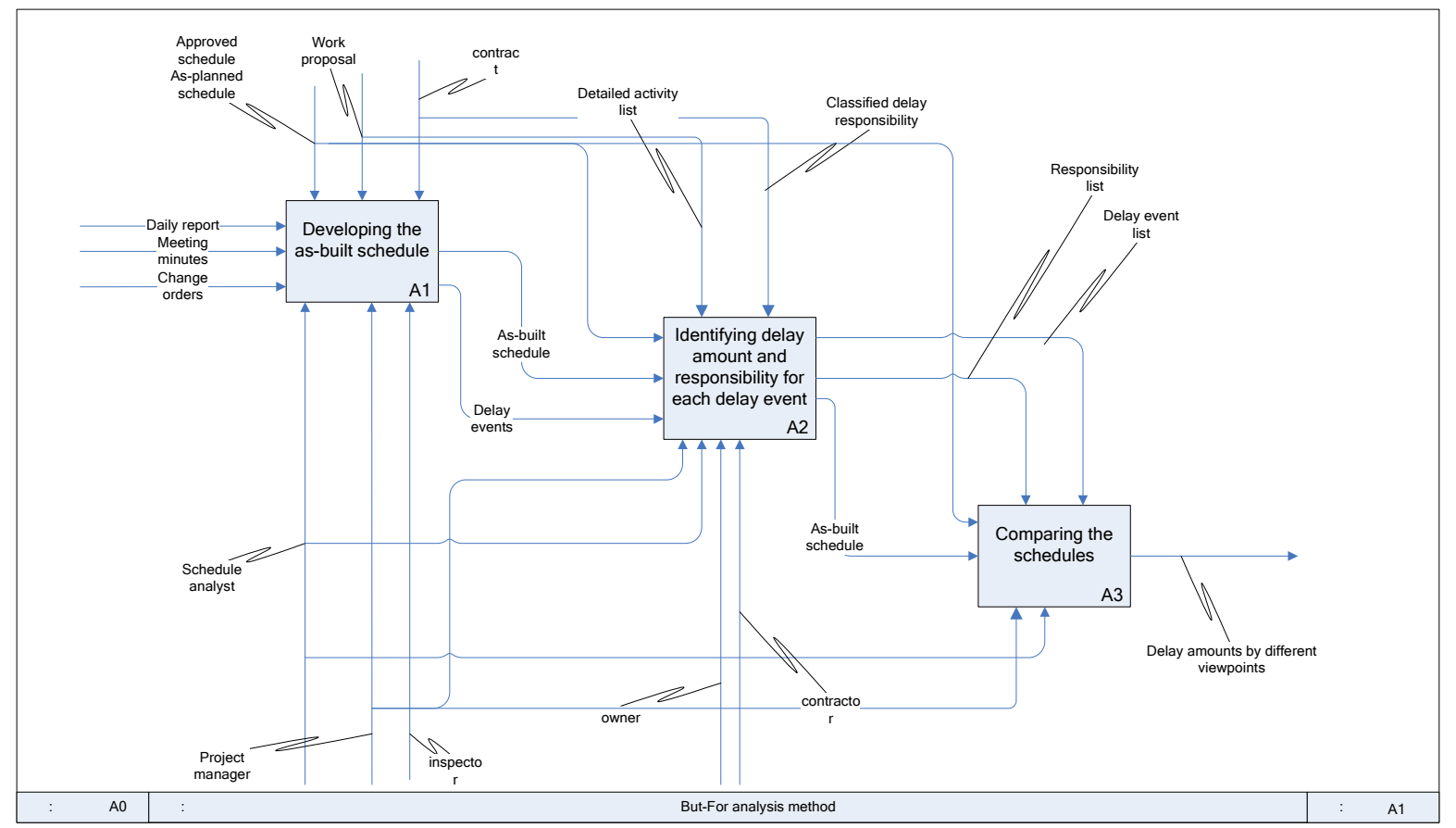

Figure 3 Analysis process for the but-for technique

\section{SIMULATION RESULTS}

Based on the analysis process shown as Figure 2, this study employed the IDEFØ to simulate the system requirement of a delay analysis MIS. Figure 3 shows the content of an IDEFØ graph for delay analysis. In that, the correlations between all activities (modeling functions) are displayed clearly. The system should at least consist of three basic functions: (1) developing the as-built schedule, (2) identifying delay amount and responsibility for each delay event, and (3) comparing the as-built and as-planned schedule.

\section{CONCLUSIONS}

Construction schedule management and delay prevention and claim preparations have received much attention from practice and researchers. There are several professional scheduling tools widely employed to plan and control construction schedules. These tools are not designated for delay analysis that requires numerous computation scenarios by different views. Therefore, a comprehensive management information system (MIS) for schedule delay analysis is required for schedule delay management. For completing a system requirement analysis, this study used the method of IDEFØ to portray the contents of an MIS for schedule delay analysis. The simulated delay analysis method is the but-for technique. The outcome of IDEFØ graphs clearly represents system functions of an MIS for delay analysis by the input, output, control, and mechanism arrows. Based on the results of this study, further system implementation will be easy to do. Although the purpose of this study is to analyze the system requirement of an MIS for delay analysis, the research results can also be used to necessary examination for delay claim preparations.

This study only simulated the most popular analysis method, the but-for technique. To incorporate more methods is required to enhance the suitability for different contract parties and different available delay information.

\section{REFERENCES}

[1] Yang, J.B., Comparison of delay analysis software for construction projects, 33rd Annual Conference of Canadian Society for Civil Engineering (CSCE), Toronto, Canada, pp. CT-115-1-9, 2005.

[2] Computer Systems Laboratory of the National Institute of Standards and Technology (NIST), Integration definition for function modeling (IDEF0), Federal Information Processing Standards Publication 183 (FIPSPUB 183), 1993.

[3] Yates, J.K., Construction decision support system for delay analysis, Journal of Construction Engineering and management, ASCE, Vol. 119, No. 2, pp. 226-244, 1993.

[4] Riad, N.I., Arditi, D. and Mohammadi, J., Computerized time impact analysis for project acceleration, Microcomputers in Civil Engineering, Vol. 10, pp. 131-146, 1995.

[5] Alkass, S., Mazerolle, M., Tribaldos, E., and Harris, F., Computer aided construction delay analysis and claims 
preparation, Construction Management and Economics, Vol. 13, No. 4, pp. 335-352, 1995.

[6] Aoude, H.M., Computerized construction delay management system, PhD dissertation, Polytechnic University, USA, 1996.

[7] Abudayyeh, O.Y., A multimedia construction delay management system, Microcomputers in Civil Engineering, Vol. 12, pp. 183-192, 1997.

[8] Ron Winter Consulting LLC, Schedule Analyzer Professional $^{\mathrm{TM}}$ software, Version, 3.05, 2004.

[9] Primavera Systems, Inc., Primavera ${ }^{\circledR}$ Claim Digger ${ }^{\mathrm{TM}}$ software, Version, 3.0, 2004.

[10]HST Software, Tipper ${ }^{\mathrm{TM}}$ software, Version, 1.1, 2004.

[11] HST Software, Sure Change ${ }^{\mathrm{TM}}$ software, Version, 1.1, 2004.

[12] Computer Systems Laboratory of the National Institute of Standards and Technology (NIST), Integration Definition for Function Modeling (IDEF0), Federal Information Processing Standards Publication 183 (FIPSPUB 183), 1993.

[13] Knowledge Based Systems, Inc., IDEFØ function modeling method, available at http:// http://www.idef.com/IDEF0.html, 2006.

[14] Sarkis, J. and Liles, D.H., Using IDEF and QFD to develop an organizational decision support methodology for the strategic justification of computer-integrated technologies, International Journal of Project Management, Vol. 13, No. 3, pp. 177-185, 1995.

[15] Chen, P.H., Wan, C., Tiong, R.L.K., Ting, S. K. and Yang Q., Augmented IDEF1-based process-oriented information modeling, Automation in Construction, Vol. 13, No. 6, pp. 735-750, 2004.

[16] Tserng, H. P. and Lin, Y. C., Developing an activity-based knowledge management system for contractors, Automation in Construction, Vol. 13, No. 6, pp. 781-802, 2004.

[17] Alkass, S., Mazerolle, M., Tribaldos, E. and Harris, F., Computer aided construction delay analysis and claims preparation. Construction Management and Economics, Vol. 13, No.4, pp. 335-352, 1995.

[18]Zack, J.G., But-for schedules-analysis and defense, Cost Engineering, Vol. 43, No. 8, pp. 13-17, 2001.

[19] Gothand, K.D., Schedule delay analysis: modified windows approach, Cost Engineering, Vol. 45, No. 9, pp. 18-23, 2003.

[20]Hegazy, T.M. and Zhang, K., Daily windows delay analysis, Journal of Construction Engineering and management, ASCE, Vol. 131, No. 5, pp. 505-512, 2005. 